Tersedia online di: http://ejournal-balitbang.kkp.go.id/index.php/bawal
e-mail:bawal.puslitbangkan@ @mail.com
BAWAL wIDYA RISET PERIKANAN TANGKAP
Volume 9 Nomor 2 Agustus 2017
p-ISSN: 1907-8226
e-ISSN: 2502-6410
BAWAL
Nomor Akreditasi: $620 /$ AU2/P2MI-LIPI/03/2015

\title{
BEBERAPA PARAMETER POPULASI UDANG PUTIH (Penaeus merguiensis de Mann) DI PERAIRAN TARAKAN, KALIMANTAN UTARA
}

\author{
SOME POPULATION PARAMETERS OF BANANA PRAWN \\ (Penaeus merguiensis de Mann) \\ IN THE TARAKAN WATERS, NORTH KALIMANTAN
}

\author{
Umi Chodrijah $^{* 1}$ dan Ali Suman ${ }^{1}$ \\ ${ }^{1}$ Peneliti pada Balai Penelitian Perikanan Laut, Jl, Raya Bogor No.507, Nanggewer Mekar, Cibinong, Bogor, Jawa Barat \\ Teregistrasi I tanggal: 26 Januari 2017; Diterima setelah perbaikan tanggal: 31 Agustus 2017; \\ Disetujui terbit tanggal: 06 September 2017
}

\begin{abstract}
ABSTRAK
Tingkat eksploitasi udang putih (Penaeus merguiensis) sangat intensif. Hal ini terindikasi dengan hasil tangkapan udang di WPP-NRI 716 selama 9 tahun terakhir meningkat. Tujuan penelitian ini untuk mengkaji beberapa parameter populasi dan aspek biologi udang putih di perairan Tarakan. Data panjang karapas dan tingkat kematangan gonad udang putih dikumpulkan dari tempat pendaratan udang di Selumit Pantai, Tarakan, Kalimantan Utara pada Januari sampai dengan November 2016. Pendugaan parameter populasi dengan aplikasi model analisis menggunakan program ELEFAN 1. Hasil penelitian menunjukkan rata-rata ukuran udang putih pertama kali tertangkap (Lc) pada panjang karapas 32,51 mm dan rata-rata ukuran pertama kali matang gonad 33,58 mm. Puncak musim pemijahan terjadi pada Maret dan Agustus. Laju pertumbuhan (K) sebesar 1,33 per tahun (betina) dan 1,55 per tahun (jantan). Laju kematian total (Z) sebesar 7,5 per tahun (betina) dan 8,85 per tahun (jantan), laju kematian alamiah (M) sebesar 1,82 per tahun (betina) dan 2,16 per tahun (jantan) serta laju kematian akibat penangkapan (F) sebesar 5,68 per tahun (betina) dan 6,69 per tahun (jantan). Laju pengusahaan (E) udang putih di perairan Tarakan adalah sebesar 0,76 per tahun. Hal ini menunjukkan tingkat pemanfaatan udang putih telah mengalami lebih tangkap (overfishing). Kondisi ini menggambarkan perlunya dilakukan pengurangan upaya sekitar $52 \%$.
\end{abstract}

Kata Kunci: Parameter populasi; udang putih; Tarakan; WPP NRI 716

\begin{abstract}
The banana prawn (Penaeus merguiensis) have been exploited intensively. For instance, within nine years the number of shrimp production in FMA 716 increased dramatically. This research aims to identify the some population parameters of banana prawn in the Tarakan waters. This research was carried out from January to November 2016. Data were analyzed using the analytical model application with ELEFAN I. The result showed that the length at first capture (Lc) of banana prawn was 32,51 $\mathrm{mmCL}$ and the length at first maturity $(\mathrm{Lm})$ was 33,58 $\mathrm{mm} C L$. The peak season of spawning period was indicated on March and August. The growth rate (K) was 1,33/year (female) and 1.55/year (male). Total mortality rate (Z) was 7.5/year (female) and 8,85/year (male), natural mortality rate $(M)$ rate was 1.82/year (female) and 2.16/year (male) and fishing mortality rate $(F)$ were 5.68/ year (female) and $6.69 / y e a r$ (male). The exploitation rate (E) of banana prawn in the Tarakan waters was 0.76 per year. Therefore, level of existing fishing effort of the banana prawn should reduced about $52 \%$ in the next year.
\end{abstract}

Keywords: Population parameter; white shrimp; Tarakan; FMA 716 


\section{PENDAHULUAN}

Udang putih (Penaeus merguiensis) merupakan salah satu komoditas penting karena memiliki permintaan dan nilai ekonomi yang tinggi. Hal ini terindikasi dengan jumlah hasil tangkapan udang putih yang terus meningkat yaitu pada tahun 2005 sebesar 61.950 ton menjadi 78.247 ton pada tahun 2013 (DJPT, 2014).

Daerah penangkapan udang putih tersebut menyebar hampir di seluruh perairan pantai, khususnya di perairan dangkal di sekitar estuari dan area mangrove seperti di perairan Tarakan (Naamin, 1977). Persentase hasil tangkapan jenis udang yang dominan di perairan ini adalah udang putih dengan produksi pada tahun 2015 sebesar 898,2 ton (Anonimus, 2015).

Aktivitas penangkapan udang putih sangat intensif dilakukan di perairan ini dan berlangsung sepanjang tahun. Peningkatan upaya penangkapan akan mengancam kelestarian dan keberlanjutan pemanfatan sumber daya udang. Sumberdaya udang termasuk sumber daya yang dapat pulih (renewable resources) akan tetapi apabila penangkapan dilakukan terus menerus tanpa adanya pembatasan akan mengakibatkan habisnya sumberdaya udang tersebut. Terkait dengan hal ini maka perlu dilakukan pengelolaan secara benar dengan pendekatan kehati-hatian agar sumber daya ini dapat diusahakan secara terus menerus dan lestari bagi peningkatan kesejahteraan nelayan. Pada tahun 2014 terlihat bahwa total hasil tangkapan semua jenis udang meningkat secara drastis (Anonimus, 2015).

Untuk mendasari pengelolaan tersebut, maka diperlukan masukan dari hasil penelitian, termasuk salah satunya hasil dari studi parameter populasi. Penelitian ini bertujuan untuk mengetahui beberapa parameter populasi udang putih (Penaeus merguiensis) yang tertangkap di perairan Tarakan, Kalimantan Utara. Informasi yang dihasilkan sangat diperlukan sebagai bahan masukan untuk pengelolaan sumberdaya udang di perairan Tarakan sehingga dapat dimanfaatkan secara berkelanjutan.

Penelitian tentang dinamika populasi udang putih telah dilakukan di beberapa perairan di Indonesia yaitu di perairan Arafura (Naamin, 1984), Cilacap (Suman, 1992; Suman \& Broer, 2005; Saputra, 2005; Saputra \& Subiyanto, 2007), Selat Madura (Setyohadi et al., 1999), Kotabaru (Suman \& Umar, 2010), Bone (Kembaren et al., 2012) dan Tarakan (Kembaren \& Suman, 2013). Penelitian ini merupakan update dari penelitian sebelumnya, yaitu evaluasi status peningkatan udang putih dari tahun ke tahun sehingga dapat dimanfaatkan secara berkelanjutan. Hasil penelitian ini diharapkan akan melengkapi dan memperbarui studi sebelumnya, untuk mendasari pengelolaan sumber daya udang putih di perairan Tarakan dan sekitarnya.

\section{BAHANDANMETODE}

Pengambilan sampel udang putih (Penaeus merguiensis) sebanyak 4.001 ekor dilakukan di tempat pendaratan udang di Selumit Pantai, Tarakan, Kalimantan Utara pada Januari sampai dengan November 2016. Sampel diperoleh dari alat tangkap pukat hela dengan ukuran mata jaring 1,5 inch dengan bagian kantongnya sebesar 1 inch. Pengumpulan data bulanan secara berkesinambungan dilakukan oleh enumerator yang sudah dilatih terlebih dulu. Panjang karapas udang diukur dengan jangka sorong (califer) dari bagian tengah supra orbital sampai ke bagian tengah posterior karapas (Sparre \& Venema, 1999). Untuk mengukur berat individu udang digunakan timbangan digital dengan ketelitian 0,5 gram.

Tingkat Kematangan gonad udang putih ditentukan secara visual sesuai dengan kriteria tingkat indeks kematangan gonad udang yang dikemukakan oleh Naamin (1984) yaitu : (1) dara (underveloped), (2) berkembang (developed), (3) hampir matang (early mature), (4) matang (ripe) dan (5) salin (spent). Pada tingkat (1) dan (2) ovarinya adalah bening (translucent), kemudian warna berubah dari pucat menjadi kuning pada tingkat (3) menjadi hijau gelap selama tingkat (4) dan hijau keabu-abuan selama tingkat (5). Tingkat kematangan gonad 1 dan 2 dikelompokkan dalam golongan belum matang (immature) dan tingkat kematangan gonad 3 dan 4 sebagai golongan matang go$\operatorname{nad}$ (mature).

\section{Analisis Data}

Sebaran frekuensi panjang karapas diperoleh dengan mentabulasikan data panjang karapas dalam tabel frekuensi dengan selang kelas $2 \mathrm{~mm}$. Pendugaan rata-rata ukuran pertama kali tertangkap (Lc) dilakukan dengan membuat grafik hubungan antara distribusi panjang kelas (sumbu $\mathrm{X}$ ) dengan jumlah udang yang dinyatakan dengan distribusi normal kumulatif estimasi (sumbu Y). Untuk memperoleh nilai Lc yaitu dengan cara menarik garis hubungan antara sumbu X dan sumbu Y untuk nilai 50\% (Sparre \& Venema, 1999). Analisa rata-rata ukuran pertama kali matang gonad digunakan metode Spearman-Karber (Udupa, 1986).

Pendugaan parameter pertumbuhan dari Von Bertalanffy yaitu panjang total asimtotik (L") dan koefisien pertumbuhan $(\mathrm{K})$ dihitung menggunakan pendekatan pergeseran bulanan modus ukuran udang. Setiap modus diturunkan melalui metoda Batacharya (1967) dalam Sparre \& Venema (1999) mewakili kelompok umur ukuran yang tertangkap. Estimasi pertumbuhan dihitung dengan menggunakan persamaan linier seperti dikemukakan oleh Gulland \& Holt (1959) dalam Sparre \& Venema (1999): 
$\frac{\Delta L}{\Delta t}=a+b^{*} L(t)$

Hubungan linier diturunkan dari persamaan von Bertalanffy sebagai berikut:

$\frac{\Delta L}{\Delta t}=K *(L \infty-L t) \quad$ dimana $\mathrm{K}=-\mathrm{b}$ dan $\mathrm{L} \infty=-\mathrm{a} / \mathrm{b}$

Estimasi pertumbuhan dihitung melalui pergeseran modus $\bar{L}$ melalui persamaan:

$\bar{L}=\frac{L(t+\Delta t)+L(t)}{2}$

Pendugaan nilai $\mathrm{t}_{\mathrm{o}}$ (umur pada saat 0 tahun berdasarkan persamaan Pauly, (1984) yaitu $\log \left(-\mathrm{t}_{\mathrm{o}}\right)=0,3922-0,2752$ $\log (\mathrm{L} \infty)-1.038 \log (\mathrm{K})$

Laju mortalitas alami (M) diduga dengan mengaplikasikan model empiris dari Pauly (1980) yaitu:

$\log (\mathrm{M})=-0,0066-0,279 * \log (\mathrm{L} \infty)+0,6543 * \log$ (K)+0,4634*Log

Dimana:

$\mathrm{L} \infty=$ panjang asimtotik $(\mathrm{mmCL})$

$\mathrm{K} \quad=$ kecepatan pertumbuhan

$\mathrm{T}=$ rataan suhu perairan di Tarakan $\left(30^{\circ} \mathrm{C}\right)$
Koefisien mortalitas total (Z) diperoleh dari kurva hasil tangkapan berdasarkan panjang (length converted catch curve) (Pauly, 1983) yang perhitungannya menggunakan paket program FISAT (Gayanilo et al., 2005). Koefisien mortalitas penangkapan $(\mathrm{F})$ dihitung dari persamaan:

$\mathrm{F}=(\mathrm{Z}-\mathrm{M})$

Laju eksploitasi (E) dihitung menggunakan persamaan:

$\mathrm{E}=\mathrm{F} / \mathrm{Z}$

\section{HASIL DAN BAHASAN \\ Hasil}

\section{Tingkat Kematangan Gonad (TKG)}

Tingkat kematangan gonad udang putih ( $P$. merguiensis) bulanan disajikan pada Gambar 1. Tingkat kematangan gonad dengan presentase matang gonad ( $m a-$ ture $=$ TKG III dan IV) tertinggi terjadi pada Maret dan Agustus.

\section{Rata-rata ukuran tertangkap $\left(L_{50 \%}\right)$ dan rata -rata ukuran matang gonad ( $\mathrm{Lm}$ )}

Hasil pengukuran terhadap 4.001 ekor udang putih diperoleh kisaran panjang karapas antara 19 -53 mmCL, sampai dengan $53 \mathrm{mmCL}$ dengan rata-rata 30,954 mmCL, seperti disajikan pada Gambar 2.

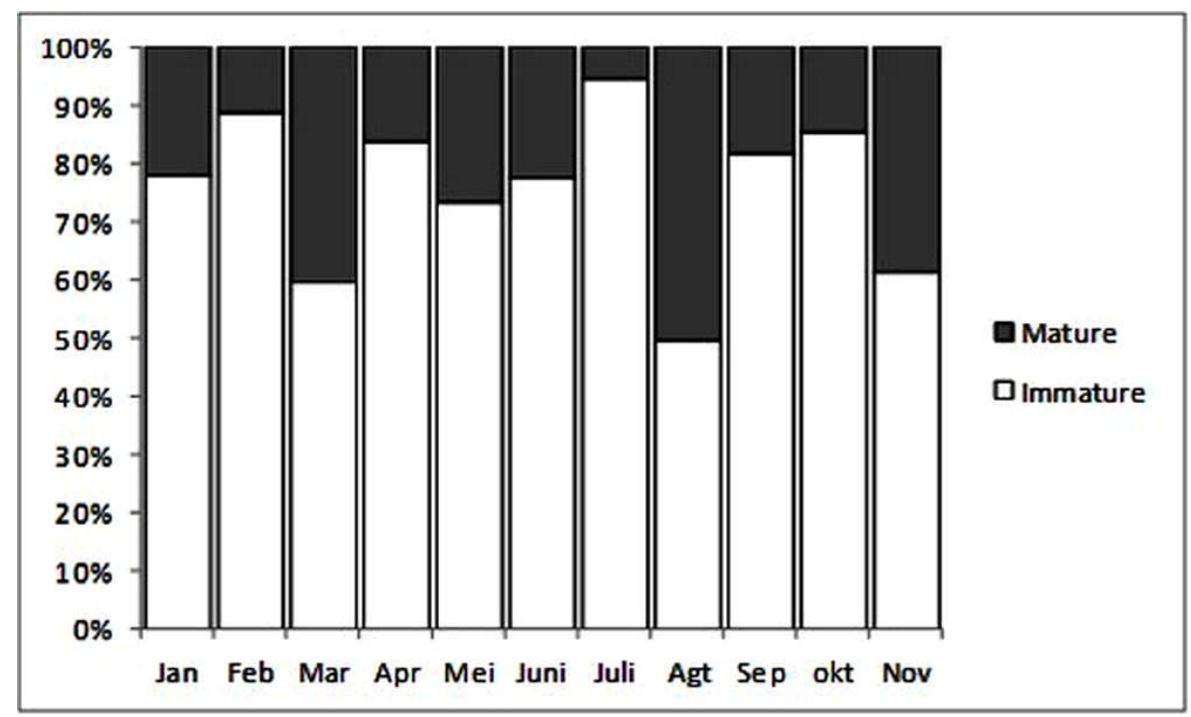

Gambar 1. Tingkat kematangan gonad udang putih, tahun 2016.

Figure 1. Maturity stage of banana prawn, 2016. 


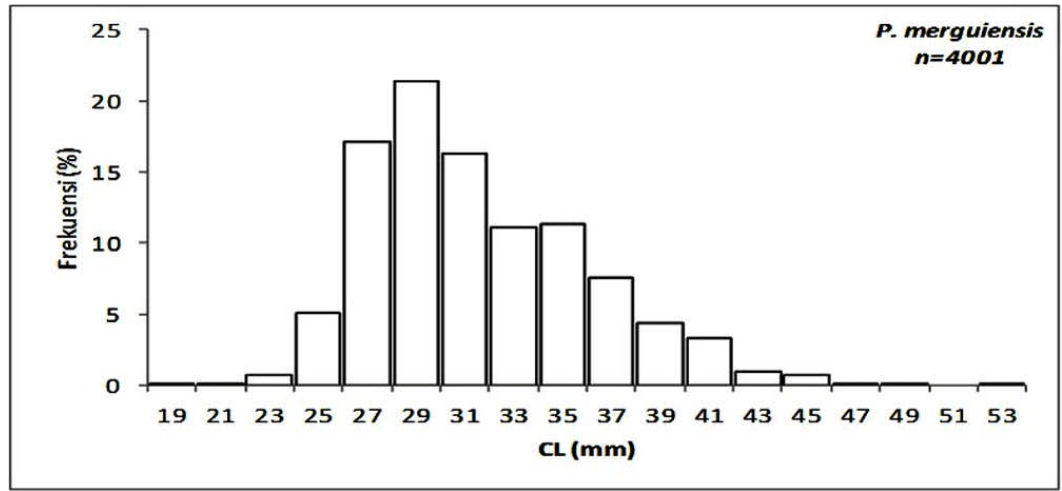

Gambar2. Sebaran panjang karapas udang putih.

Figure 2. Carapace length distribution of banana prawn.

Berdasarkan hasil analisis menggunakan SpearmanKarber (Udupa, 1986) diperoleh panjang pertama kali matang gonad (length at first maturity-Lm) pada ukuran 33,58 mmCL, sedangkan nilai rata-rata panjang tertangkap
$\left(\mathrm{L}_{50 \%}\right)$ dimana menunjukkan $50 \%$ dari udang yang tertangkap pukat hela dengan ukuran mata jaring 1,5 inch dan kantong sebesar 1 inch terdapat pada ukuran 32,51 mmCL (Gambar 3).

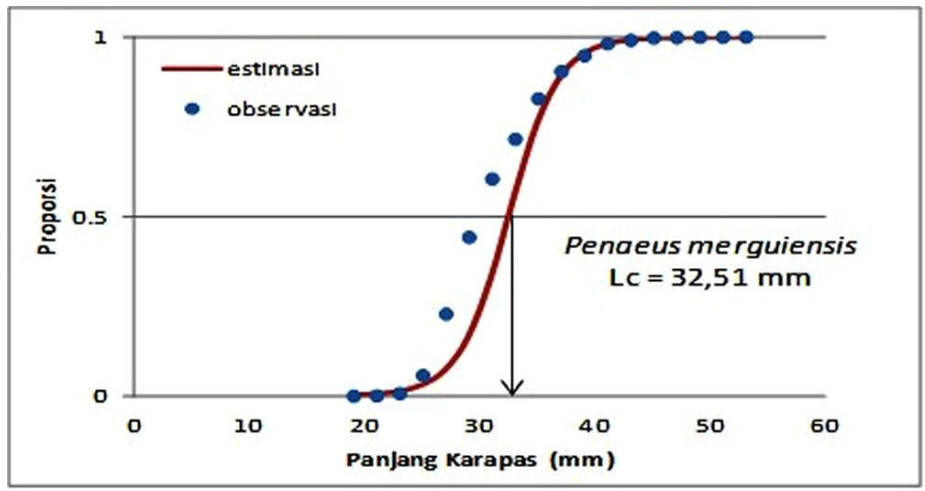

Gambar 3. Frekuensi kumulatif dari distribusi frekuensi panjang udang putih.

Figure 3. Cumulative frequency of the length frequency distribution of banana prawn.

\section{Parameter Populasi}

Data sebaran frekuensi panjang karapas udang putih setiap bulan di perairan Tarakan disajikan pada Gambar 4.

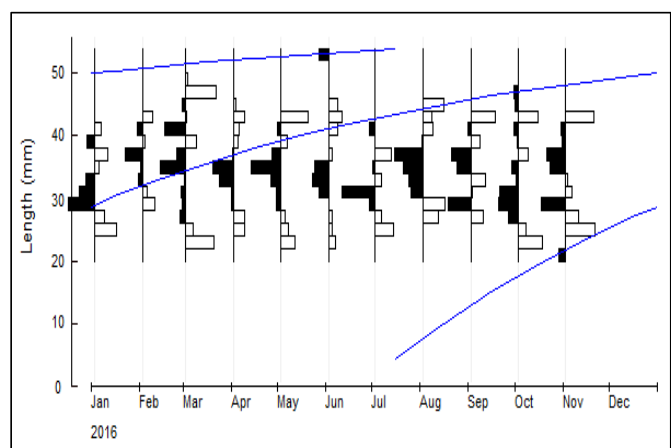

Betina (female)
Analisa menggunakan program ELEFAN diperoleh panjang karapas asimtotik (CL.) sebesar 57,6 mm (betina) dan 45,2 mm (jantan) dengan laju pertumbuhan $(\mathrm{K})$ sebesar 1,33/ tahun (betina) dan 1,55/tahun (jantan.).

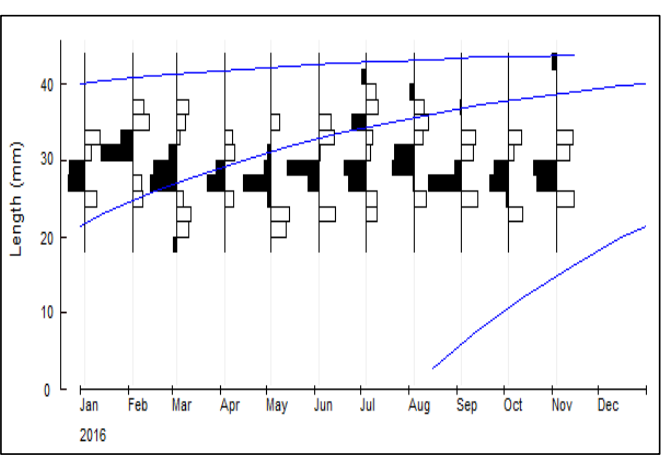

Jantan (male)

Gambar4. Kurva pertumbuhan udang putih.

Figure 4. Growth curve of banana prawn. 
Hasil analisa parameter populasi menunjukkan bahwa laju kematian alamiah (M) udang putih sebesar 1,82 per tahun (betina) dan 2,16 per tahun (jantan), laju kematian akibat penangkapan $(\mathrm{F})$ sebesar 5,68 per tahun (betina) dan 6,69 per tahun (jantan), serta laju kematian total (Z) sebesar 7,5 per tahun (betina) dan 8,85 per tahun (jantan).

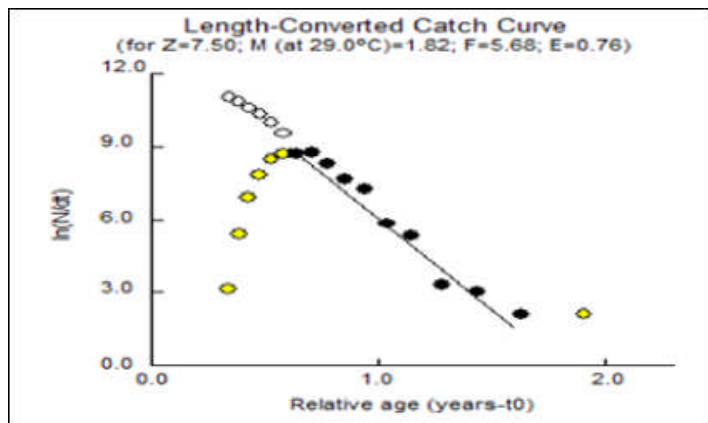

Betina (female)
Kurva hasil tangkapan yang dilinierkan berdasarkan panjang karapas dengan kemiringan (slope) sebagai nilai $\mathrm{Z}$ disajikan pada Gambar 5 dan pada Gambar 6 disajikan kurva pertumbuhan von Bertalanffy dari udang putih berdasarkan umur dan panjang karapas udang.

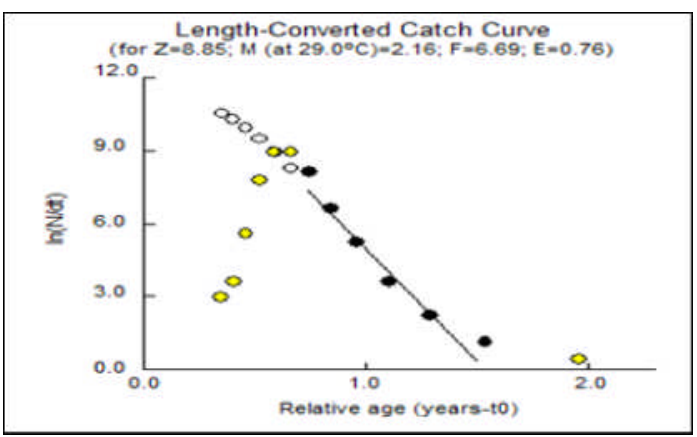

Jantan (male)

Gambar 5. Nilai Z sebagai slope kurva hasil tangkapan yang dilinierkan berdasarkan rata-rata komposisi umur. Figure 5. The value of total mortality $(Z)$ as slope of age converted catch curve.

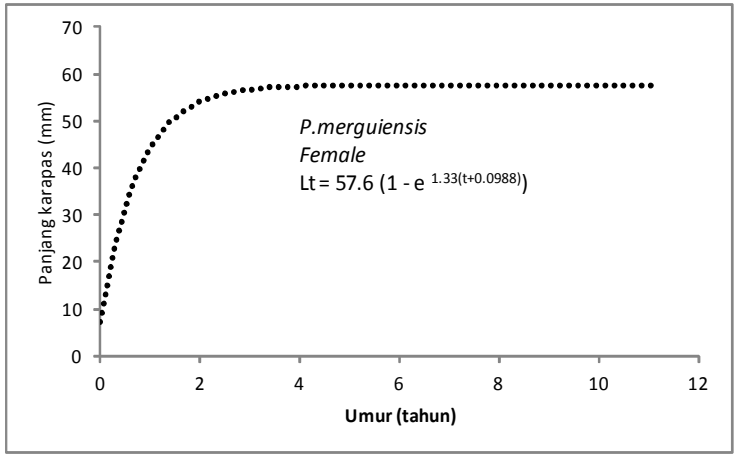

Betina (female)

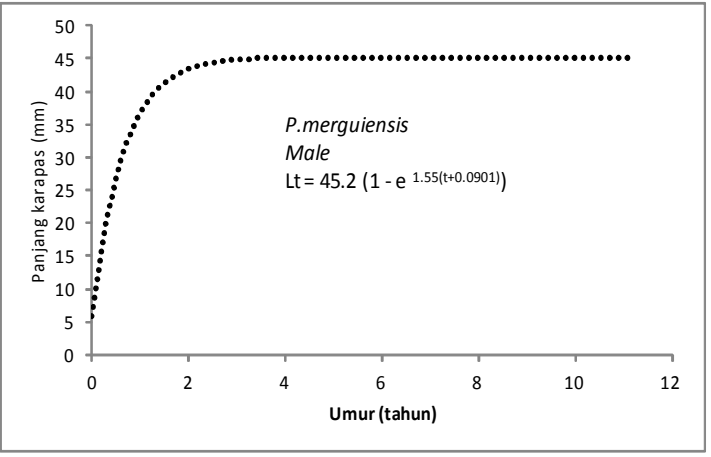

Jantan (male)

Gambar 6. Kurva pertumbuhan von Bertalanffy udang putih berdasarkan nilai $\mathrm{K}=1,33 / \mathrm{th}, \mathrm{L},=57,6 \mathrm{mmCL}$ (betina) dan $\mathrm{K}=1,55 /$ th, $\mathrm{L}_{\text {, }}=45,2 \mathrm{mmCL}$ (jantan).

Figure 6. Von Bertalanffy growth curve of banana prawn in term of $K=1,33 / y r$ and $L_{,}=57,6 \mathrm{mmCL}$ (female) and $K=1,55 / y r$ and $L_{,}=45,2 \mathrm{mmCL}$ (male).

\section{Bahasan}

Sebaran panjang karapas udang putih (Penaeus merguiensis) di perairan Tarakan berkisar antara 19 - 53 mmCL. Hasil penelitian Tirtadanu et al. (2016) menyatakan bahwa di perairan Utara Jawa Tengah panjang karapas udang jerbung jantan (Penaeus merguiensis) berkisar antara 20 - $62 \mathrm{~mm}$ (jantan) dan 14-68 mm (betina). Ukuran panjang karapas tersebur terlihat lebih kecil di perairan Tarakan dibanding di Laut Jawa. Adanya perbedaan ukuran tersebut kemungkinan dipengaruhi oleh kondisi lingkungan, alat tangkap dan tekanan penangkapan.

Rata-rata panjang ukuran matang gonad $(\mathrm{Lm}=33.51$ mmCL) lebih besar daripada rata-rata ukuran panjang tertangkap $\left(\mathrm{L}_{\mathrm{C}}=32,51\right)$. Hal ini mengindikasikan bahwa kondisi udang putih di perairan ini sudah mulai terancam karena udang-udang tersebut sudah terlebih dahulu tertangkap sebelum matang gonad. Jika hal tersebut berlangsung terus menerus dapat mengakibatkan penurunan stok udang. Hal yang sama terjadi di perairan Dolak, yaitu rata-rata ukuran panjang pertama tertangkap (27,78 mmCL) lebih kecil dari rata-rata panjang pertama kali matang gonad (38,7 mmCL) (Hargiyatno et al., 2013). Hasil penelitian Saputra et al., (2013) juga menyatakan bahwa udang putih di Cilacap tertangkap sebelum matang gonad dan didominasi oleh TKG I sebesar $85,35 \%$. Sementara itu hasil yang berbeda didapatkan Kembaren \& Suman (2013), yang menemukan nilai Lc udang putih di perairan Tarakan sebesar $35 \mathrm{mmCL}$ dan nilai Lm 33,8 mmCL. Hasil penelitian yang sama didapatkan Tirtadanu et al., (2016) yang menyatakan bahwa di perairan Utara Jawa Tengah, nilai Lc (29,4 mm) lebih rendah daripada nilai $\operatorname{Lm}(42,85 \mathrm{~mm})$, yang berarti rata-rata udang yang tertangkap merupakan udang yang belum matang gonad. Adanya perbedaan nilai Lc di perairan Tarakan dibanding hasil penelitian sebelumnya 
(Kembaren \& Suman, 2013) menunjukkan bahwa tekanan penangkapan yang sangat intensif di perairan ini telah berdampak pada penurunan ukuran udang yang tertangkap. Hal ini mengindikasikan terjadinya overfishing pada pengusahaan udang putih di perairan Tarakan dan sekitarnya.

Berdasarkan hasil analisa tingkat kematangan gonad bulanan diperoleh musim pemijahan udang putih terjadi sepanjang tahun, namun demikian puncak pemijahan diduga terjadi pada bulan Maret dan Agustus, dimana pada bulan-bulan tersebut persentase udang putih yang matang gonad lebih besar dari pada bulan - bulan yang lainnya. Hasil penelitian ini berbeda dengan penelitian sebelumnya yaitu menurut Nurdin et al, (2015) menyatakan bahwa puncak musim udang putih di perairan Sampit terjadi pada bulan Maret dan September. Perbedaan ini diduga disebabkan oleh perbedaan kondisi geografis seperti curah hujan dimasing-masing lokasi. Naamin (1984) menyatakan bahwa curah hujan berkaitan dengan puncak musim bertelur udang yang biasanya terjadi pada awal dan akhir musim penghujan.

Panjang karapas asimtotik (CL") dan laju pertumbuhan (K) udang putih di perairan Tarakan, Kalimantan Utara masing-masing sebesar 57,6 mm (betina) dan 45,2 $\mathrm{mm}$ (jantan) dengan laju pertumbuhan $(\mathrm{K})$ sebesar 1,33 per tahun (betina) dan 1,55 pertahun (jantan.). Hasil penelitian ini berbeda dengan hasil penelitian Suman \& Umar (2010) yang mendapatkan panjang asimtotik dan laju pertumbuhan udang putih di perairan Kotabaru sebesar 44,3 mm dan 1,4 per tahun. Di perairan Cilacap didapatkan nilai Loo sebesar 37,5 mm dan nilai K sebesar 1,4 per tahun (Saputra \& Subiyanto, 2007) dan diperairan Bone nilai $\mathrm{L}_{\infty}$ sebesar $39 \mathrm{~mm}$ dan nilai K 1,2 per tahun (Kembaren et al., 2012) serta di perairan Sampit nilai $L_{\infty}$ sebesar $57,8 \mathrm{~mm}$ dan nilai K sebagai 1,45 per tahun (Nurdin et al., 2015), sementara di perairan Cilacap, Jawa Tengah didapatkan nilai Loo sebesar 63,58 mmCL (betina) dan 60,42 mm (jantan) (Saputra et al., 2013). Perbedaan pertumbuhan tersebut diduga karena kelimpahan makanan yang berbeda dan pengaruh kondisi lingkungan perairan pada masingmasing perairan (Effendie, 1997). Selain itu terlihat nilai K udang putih selalu di atas nilai 1 dan hal ini menunjukkan bahwa udang putih memiliki pertumbuhan yang cepat dan udang putih termasuk yang mampu melakukan pembaruan populasi secara cepat (Sparre \& Venema, 1999).

Laju kematian alamiah (M) udang putih di perairan Tarakan sebesar 1,82 pertahun (betina) dan 2,16 pertahun (jantan), laju kematian akibat penangkapan (F) sebesar 5,68 per tahun (betina) dan 6,69 per tahun (jantan), serta laju kematian total $(Z)$ sebesar 7,5 per tahun (betina) dan 8,85 per tahun (jantan). Hasil penelitian ini tidak berbeda dengan hasil penelitian Saputra \& Subiyato, (2007), yang menyatakan bahwa di perairan Cilacap laju kematian total udang putih sebesar 7,02 per tahun, laju kematian alami 1,96 per tahun, dan laju kematian karena penangkapan sebesar 5,06 pertahun, sedangkan di perairan Kotabaru diperoleh laju kematian total (Z) udang putih sebesar 4,52 per tahun dan laju kematian alami 1,96 per tahun (Suman \& Umar, 2010), sementara itu Kembaren et al., (2012) menyatakan bahwa di perairan Bone laju kematian total, laju kematian alami dan laju kematian karena penangkapan udang putih masing-masing sebesar 7,86 per tahun, 1,90 per tahun, dan 5,96 per tahun. Hasil penelitian Kembaren \& Suman (2013) di perairan Tarakan mendapatkan laju kematian total, laju kematian alami dan laju kematian karena penangkapan udang putih masing-masing sebesar 4,85 per tahun, 1,76 per tahun, dan 3,09 per tahun. Perbedaan hasil penelitian dengan penelitian sebelumnya di masing-masing perairan diduga karena pengaruh perbedaan besarnya upaya penangkapan yang dilakukan di masing-masing lokasi dan kemampuan operasional penangkapan dari alat tangkap yang digunakan. Suman \& Umar (2010) menyatakan bahwa laju kematian karena penangkapan (F) bervariasi menurut keragaman upaya pennagkapan setiap tahunnya. Laju kematian karena penangkapan $(\mathrm{F})$ di perairan Tarakan dan perairan lainnya terlihat selalu lebih besar dari nilai laju kematian alaminya (M). Hal ini menunjukkan bahwa kematian udang putih di perairan Tarakan dan perairan lainnya sangat ditentukan oleh tekanan penangkapan. Dalam kaitan tersebut maka pengendalian upaya penangkapan inilah yang terutama harus dilakukan untuk melestarikan sumber daya udang ini.

Tingkat pengusahaan (E) udang putih di perairan Tarakan sebesar 0,76. Menurut Pauly et al., (1984), pemanfaatan sumber daya ikan yang optimal dicapai pada saat nilai $\mathrm{E}=0,5$. Dengan demikian tingkat pengusahaan udang di perairan Tarakan dikatakan sudah melebihi optimalnya sebesar $52 \%$. Hal ini didukung oleh laju kematian akibat penangkapan yang cukup tinggi. Hasil penelitian lainnya diperoleh nilai laju pengusahaan (E) di perairan Kota baru sebesar 0,56 per tahun, di perairan Segara Anakan Cilacap sebagai 0,72 per tahun, di perairan Bone sebagai 0,76 per tahun serta di perairan Tarakan sebagai 0,64 per tahun (Suman \& Umar, 2010, Saputra \& Subiyanto, 2007; Kembaren et al., 2012; Kembaren \& Suman, 2013). Perbedaan laju pengusahaan di setiap perairan diduga karena efektifitas alat tangkap yang berbeda atau struktur populasi yang berbeda pula. Tingginya laju pengusahaan ini memerlukan tindakan pengelolaan untuk kelestarian sumberdaya udang.

\section{KESIMPULAN}

Penelitian udang putih (Penaeus merguiensis) di perairan Tarakan diperoleh parameter populasi udang jantan dan betina berbeda. Ukuran panjang karapas udang jantan umumnya lebih kecil, sebaliknya laju pertumbuhan 
dan laju kematiannya lebih besar. Rata-rata ukuran pertama kali tertangkap (Lc) adalah pada panjang karapas 32,51 mm dan rata-rata ukuran matang gonad (Lm)udang betina adalah 33,58 mmCL. Udang putih terlebih dahulu tertangkap sebelum mencapai ukuran matang gonad (Lc $<\mathrm{Lm}$ ). Laju pengusahaan udang putih sudah berada dalam tahapan overfishing $(\mathrm{E}=0,76)$ Agar kelestarian sumber daya udang putih di perairan Tarakan terjamin kelestariannya, maka harus dilakukan pengelolaan dengan mengurangi upaya sebesar $52 \%$ dari upaya penangkapan udang putih pada saat ini.

\section{PERSANTUNAN}

Tulisan ini merupakan bagian dari kegiatan penelitian karakteristik biologi perikanan, habitat sumber daya ikan dan potensi produksi sumberdaya perikanan di WPP716 (Laut Sulawesi dan sebelah Utara Pulau Halmahera) pada Balai Penelitian Perikanan Laut Muara Baru, Jakarta Tahun Anggaran 2016. Penulis juga mengucapkan terima kasih kepada petugas enumerator di Tarakan yang telah membantu dalam pengumpulan data selama penelitian.

\section{DAFTAR PUSTAKA}

Anonimus, (2015). Laporan statistik perikanan 2014 (p. 71). Dinas Kelautan dan Perikanan Kota Tarakan.

DJPT, (2014). Statistik perikanan tangkap menurut wilayah pengelolaan perikanan Negara Republik Indonesia (WPP-NRI) 2005-2013.484 hal.

Effendie, M.I. (1997). Biologi perikanan (p. 163). Penerbit Yayasan Pusaka Nusatama. Yogyakarta.

Gayanilo, F.C.Jr., Sparre, P., \& Pauly, D. (2005). FAOICLARM Stock Assessment Tools II (FiSAT II) (p. 168). Revised version. User's guide. FAO Computerized Information Series (Fisheries). No. 8. Revised version. Rome, FAO.

Gulland, J.A. (1983). Fish stock assessment (p. 233). A manual of Basic Methods. John Wiley \& Sons. Chicester

Hargiyatno, I.T, Sumiono, B., \& Suharyanto. (2013). Laju tangkap, kepadatan stok, dan beberapa aspek biologi udang putih (Penaeus merguiensis) di Perairan Dolak, Laut Arafura. BAWAL, 5(2), 123-129.

Kembaren, D.D., Sumiono, B., \& Suprapto. (2012). Biologi dan parameter perrtumbuhan udang putih (Penaeus merguiensis) di perairan Bone, Sulawesi Selatan. Dalam Suman, A., Wudianto \& B. Sumiono (Eds.), Status pemanfataan sumberdaya ikan di perairan Selat
Makasar, Teluk Bone, Laut Flores dan Laut Banda. Bogor. IPB Press. p. 1-13.

Kembaren, D.D \& Suman, A. (2013). Biology and population dynamics of Banana shrimp (Penaeus merguiensis) in the Tarakan waters, East Borneo. Ind.Fish.Res.J. 19(2), 99-105.

King, M. (1995). Fisheries biology: assessment and management (p. 341). Fishing News Books.

Naamin, N. (1977). Perkembangan perikanan udang di Indonesia. Prosiding Seminar II Perikanan Udang. Maret 1977. LPPL. Jakarta. p. 55-56.

Naamin, N. (1984). Dinamika populasi udang putih (Penarus merguiensis de Mann) di perairan Arafura dan alternativ pengelolaannya (p. 277). Desertasi. Fakultas Pasca Sarjana. Institut Pertanian Bogor.

Nurdin, E \& Kembaren, D.D. (2015). Parameter populasi udang putih (Penaeus merguiensis) di Perairan Sampit dan sekitarnya, Kalimantan Tengah. J.Lit.Perik.Ind. 7(2), 103-109.

Pauly, D. (1980). On the interrelationship between natural mortality, grwoth parameters, and mean environmental temperature in 175 fish stocks. J. Com. CIEM. 39 (2), 175-192.

Pauly, D. (1983). Some smple methods for the assessment of tropical fish stock. FAO Fisheries Technical Paper. (254), 52p.

Pauly, D., Ingles, J., \& Neal, R. (1984). Application to shrimp stocks of objective methods for the estimation of growth, morlality, and recruitment related parameters from lemgth frequency data (ELEFAN I and II). In Penaeid Shrimp-Their Biology \& Management. Fishing News Book Limited. Farnham-Surrey-England. p. 220234.

Saputra, S. W. (2005). Dinamika populasi udang jari (Metapenaeus elegans De Mann 1907) dan Pengelolaannya di Laguna Segara Anakan Cilacap Jawa Tengah. Desertasi. Sekolah Pasca Sarjanan. Bogor. Institut Pertanian Bogor. 235 hal.

Saputra, S.W, \& Subiyanto. (2007). Dinamika populasi udang putih (Penaeus merguiensis de Mann 1907) di Laguna Segara Anakan, Cilacap, Jawa Tengah. Ilmu Kelautan. Universitas Diponegoro. 12(3), 157-166.

Saputra, S.W., Djuwito, A. Rutiyaningsih. (2013). Beberapa aspek biologi udang jerbung (Penaeus merguiensis) 
di perairan pantai Cilacap Jawa Tengah. Journal of Management of Aquatic Resources. 2(3), 47-55.

Setyohadi, D., D. Nugroho, T.J. Lelono, D.G.R. Wiadnya., \& Martinus. (1999). Biologi dan distribusi sumber daya udang penaeid berdasarkan hasil tangkapan di Selat Madura. Laporan Penelitian Litbang Pertanian. p. 50-61.

Sparre, P \& Venema, S.C. (1999). Introduksi pengkajian ikan tropis (p. 438 ). Buku 1: Manual. Terjemahan. Pusat Penelitian dan Pengembangan Perikanan. Jakarta.

Suman, A. (1992). Population dynamics of endeavour shrimp (Metapenaeus ensis de Haan) in the Southern inshore of Java. Proceeding of the First Seminar on Marine and Coastal Ecology. 64-71 (in Indonesian).
Suman, A\& Boer, M. (2005). Size at first maturity, spawning season and growth parameters of endeavour shrimp (Metapenaeus ensis de Hann) in Cilacap and adjacent waters. Ind.Fish.Res.J. 11 (2), 65-71.

Suman, A \& Umar, C. (2010). Dinamika populasi udang putih (Penaeus merguiensis de Mann) di perairan Kotabaru, Kalimantan Selatan. J.Lit.Perik.Ind. 16 (1), 29-33.

Tirtadanu \& Ernawati, T. (2016). Kajian biologi udang jerbung (Penaeus merguiensis de Mann, 1888) di perairan Utara Jawa Tengah. BAWAL. 8 (2), 109-116.

Udupa, K. S. (1986). Statistical method of estimating the size at first maturity in fishes. Fishbyte 4. ICLARM. 810. 